Session 1692

\title{
Building An Engineer: Women in Engineering
}

\author{
Suzanne B. Heyman, Aisha K. Lawrey, \& Ronald H. Rockland \\ New Jersey Institute of Technology
}

\begin{abstract}
Even as gender gaps in education decrease, barriers to equal education for women in advanced mathematics, science, and technology remain. Such obstacles translate to few women entering careers in technology fields, resulting in lower wages for women and limited career opportunities. Gender differences in mathematics and science appear to grow as students progress through high school. In college, fewer females are found in advanced mathematics and science courses.

To address these issues, the Pre-Engineering Instructional and Outreach Program (PrE-IOP), a collaboration of the Newark College of Engineering and New Jersey Institute of Technology's (NJT) Center for Pre-College Programs, was created. This program seeks to increase the future pool of qualified high-tech workers, including women and minorities. PrE-IOP consists of two components:
\end{abstract}

1. An instructional component that implements pre-engineering curriculum in middle and high school classes.

2. An outreach component that consists of a comprehensive information campaign about the rewards of engineering and technology professions.

One project of the outreach component is a series of teleconferences on the theme of "Building an Engineer" designed to introduce middle and high school educators to engineering and engineering education. "Building an Engineer: Women in Engineering," our second teleconference of this series, deals with gender issues in engineering education and engineering careers. After participating in this teleconference, educators will be better informed of the shortage of female engineers, the importance of encouraging young women to take advanced math and science courses, and how to help female students build confidence in their mathematics and science abilities.

\section{Introduction}

The 21 st century economy demands an educated workforce, particularly in science, technology, engineering and mathematics (STEM). The number of students selecting engineering as a major is low both nationally and in New Jersey, even though the workplace is increasing its demand for 
engineering and engineering related professionals ${ }^{[11]}$.

The Pre-Engineering Instructional and Outreach Program (PrE-IOP) was created at New Jersey Institute of Technology in 2001 to address this need. This program, funded by the New Jersey Commission on Higher Education, is a joint program of NJIT's Newark College of Engineering and NJIT's Center for Pre-College Programs. The main goal of this program is to enlarge the future pool of qualified high-tech workers in New Jersey, including those who have been historically underrepresented (such as minorities and women).

PrE-IOP is based on the assumption that effective science/pre-engineering secondary school curricula (and effective teacher training), coupled with better understanding of the profession would eventually lead to significant increases in engineering enrollment. Hence, this comprehensive program has two major components: the instructional component and the outreach component.

The Instructional component, under the auspices of an Education and Training Institute, includes the adaptation and/or development of pre-engineering curricula for use in middle and high school science and mathematics classrooms and the provision of institutes for teacher professional development. The Outreach component involves the implementation of an "Engineering the Future" outreach program and the formation of alliances with three groups of stakeholders: educators, counselors and parents.

This paper will discuss PrE-IOP's "Building an Engineer" teleconference series. Details will be given on the first teleconference titled "Building an Engineer: How to Help Our Students" and will discuss how a segment about women and minorities in engineering led to the topic for the second teleconference "Building an Engineer: Women in Engineering" that is scheduled for May 6th, 2003.

\section{Underrepresentation of women in engineering}

Studies have shown that the gender gap in areas such as science and mathematics has narrowed ${ }^{[1]}$, and many women are now going into fields once dominated by males, such as law, medicine and dentistry. However, engineering still continues to show the greatest inequity between male and female undergraduate students ${ }^{[2]}$.

According to the National Association of Colleges and Employers, of the 2 million working engineers less than $10 \%$ of American engineers are women ${ }^{[3]}$. Engineering must welcome women or risk becoming marginalized as other fields seek out and make a place for them ${ }^{[4]}$.

The low representation of women in engineering is well known. It was once believed that many young women entering college did not have sufficient math and science backgrounds to pursue engineering degrees ${ }^{[10]}$. However, recent studies show that even young women with adequate backgrounds in math and science, are not entering the engineering field ${ }^{[9]}$. The reasons are many, including a serious deficiency in educational resources, social pressure resulting from the negative social image of scientists and engineers, a lack of encouragement (coupled with active discouragement), not enough hands-on experiments in science, engineering and technology for girls, and the lack of women role models in the profession ${ }^{[10]}$. 
One potential solution is an aggressive, focused intervention effort at each educational stage and transition, which targets girls at the pre-collegiate level by exposing them to engineering programs and female role models. It has been said that women lack confidence in their math and science abilities that discourages interest in engineering before they even enter college. If we expose girls at an earlier age to engineering more girls will be able to decide if they want to consider it as a major when they enter college.

This implementation to all the stakeholders is critically important in increasing the engineering enrollment, especially with under-represented minorities. To address this under representation of women in STEM fields, there have been several initiatives at NJIT ${ }^{[5,6]}$ and other institutions ${ }^{\text {[such as }}$

${ }^{7,8]}$ to encourage female students in pursue these fields. These programs include hands-on research, mentoring, and linking engineering and technology to real world applications.

One of the factors that should be addressed to overcome this divergence of female enrollment is the impact teachers, parents, and counselors have on a student's choice in career. If educators do not understand the role of engineering in society, and what career paths an engineering student can take, then these stakeholders will not be an effective influence with regard to their student's choice of engineering as a career. It is, therefore, important for educators, parents and counselors to better understand what engineers do, as well as why many women and underrepresented minorities choose not to enter engineering.

\section{Overview of Teleconference}

To help teachers and other stakeholders understand the role of engineering, and to reach the largest number of middle and high students, the Engineering the Future Outreach program undertook the development of the "Building an Engineer" teleconference series. The first teleconference titled "Building an Engineer: How to Help Our Students" which took place in the Fall of 2002 introduced middle school and high school educators to experts in the field of engineering and engineering education. The purpose was to have a simple, organized structure for a diverse group of experts to discuss information concerning preparing for college, how students can have fun with engineering, entering and graduating form engineering colleges, identifying issuses women and minorities in engineering, and entering industry.

The primary goal was for participants to take what they learned from the teleconference back to their schools to enhance their students' knowledge about engineering. Participants could then relay their own visions for the future of engineering for their students, identify ways for addressing these issues, select strategies to address perceived problems or misconceptions, and develop an implementation plan for reaching those visions.

\section{Topics}

The teleconference was organized into four segments each with a group of three panelists. Topics of importance to pursuing and attracting students to the engineering field were highlighted in each segment. The moderator, who coordinated all the segments, asked questions of the panelists to 
prompt discussion on the various topics. At the beginning of each section the moderator introduced video clips of professional engineers discussing issues that were relevant to the subject matter at hand.

The teleconference segments were:

- Preparation for College: In this segment the panelists were a middle school teacher, a high school guidance counselor, and a parent of an engineer. The middle school teacher talked about how he gets his students interested in engineering and how they react to the projects he has them work on. The high school guidance counselor spoke about which students he typically recommends for engineering, the skills those students possess, and whether he would recommend a student with poor math and science skills to go into engineering. The parent talked about how and when her daughter became interested in engineering, and how involved she as a parent was in her daughter's decision to choose engineering as a career.

- Fun Engineering: In this segment the panelists consisted of a high school teacher, an engineer from a professional engineering organization, and the associate director of a center for pre-college programs. The high school teacher explained how she formed an engineering club in her school and how students who join these clubs would participate in programs, and competitions. The engineer talked about how the National Society of Black Engineers influenced him in becoming an engineer and how this organization provides outreach for secondary schools. The associate director introduced engineering programs offered by NJIT's Center for Pre-College Programs.

- College Life: In this segment the panelists consisted of a four year college professor, a two year college professor, and an engineering student. The panelists discussed the courses which are building blocks for an engineering student and the different engineering disciplines. The four-year college professor spoke about the structure and topics included in the Fundamentals of Engineering Design courses she helped to develop and how this course benefits first year engineering students. The community college professor brought up the benefits of attending a community college and how they prepare students to enter a four year college as an engineering major. The engineering student talked his experiences as an engineering student, misconceptions about engineering and how he became interested in engineering.

- Women in Engineering / Minorities in Engineering / Industry: In this segment the panelists consisted of a female engineer, a program director of a foundation, and the director of the equal opportunity program. Issues addressed in this segment were the challenges faced by minorities in engineering, women in engineering, and issues faced by engineers in the workplace. Discussion topics included having a family along with a career, the importance of support programs for women on college campuses, and job placement upon graduation. 


\section{Structure and technical information}

The first teleconference of the "Building An Engineer" series took place on November 20, 2002 from 3:30 to 5:30 pm. Around 150 middle and high school teachers and counselors viewed the teleconference from twenty sites via a Steerable Satellite Receiver on KU Band or on a Verizon IDLS channel. The sites were made up of secondary schools and community colleges throughout the state of New Jersey. The teleconference was offered free of charge and each of the participants received two professional credit hours for attending.

To solicit participants for the teleconference letters were sent to middle and high school principals and to all the superintendents in the New Jersey School district. Letters were also sent to all the private schools in the area. The letters included details on the upcoming conference, how to sign up for the conference and a request for schools to act as a host site.

In planning for the teleconference a great deal of thought was given to what topics should be covered and how much time to devote to each topic. Another consideration was the types of "experts" that would be included on the panel for each segment. Once a description of the type of people for the panel was determined, various university and community members were contacted. We were very fortunate to have so many intelligent and well-informed panelist members available on the day of our teleconference.

Engineers for the introductory video clips were solicited through the use of the NJIT alumni database, precollege programs alumni database and various personal and professional contacts. It took two and a half weeks to collect eighteen 30 minute video interviews of professional engineers. The four weeks to follow were spent reviewing and editing the footage into the introductory segments. Although the precollege staff conducted all the interviews and made all the decisions on editing, the media services department at NJIT did all the videotaping and editing.

In order to ensure that the teleconference experience was as comfortable and informative for the participants as possible we provided two breaks and an intermission. The breaks were each two minutes long and the intermission was ten minutes. During the breaks we provided written followup information to supplement the discussion that had just taken place in the previous segment.

Although the teleconference was live, the moderator's introductory and concluding remarks for each segment were scripted. The moderator also had predetermined questions to ask each panelist and the panelists' received a list of these questions in advance. The viewers were then allowed to call, fax, or e-mail in additional questions.

At each site we distributed a sign-in sheet, agendas, and teleconference evaluation forms. All participants signed in as they arrived at the site and provided us with their contact information. The agenda was provided so that the participants knew what to expect from the conference. The phone number, e-mail address, and fax number was also provided on the agenda so that the participants could ask questions throughout the conference. The teleconference evaluation form 
was used to get feedback from the participants. The contact person at each site collected the sign in sheet and the evaluation forms and mailed them back to our office.

\section{Feedback and evaluation}

The evaluation form was designed to determine the quality of the production and how well the conference was received by the audience. Some questions that were included in the evaluation were if the teleconference met the participant's expectations, how knowledgeable the panelists were about the topic, how satisfied the participants were with the amount of information delivered on each topic, how useful the engineer videos were, how organized the teleconference was, if they would recommend this teleconference to colleagues, and any recommendations for future teleconferences.

After viewing the teleconference, participants said they were better informed about engineering as a career, how to interest students at an early age, and where to get information on engineering. When the participants were asked which information from the teleconference they would share with their students, we received a variety of responses. Some expressed that they would encourage both male and female students to pursue engineering by getting involved in competitions and engineering programs. Others thought that they should let their students know about community college as a viable option. Some participants were going to pass along information on what engineers do, and different types of engineering. These educators also expressed that they were going to encourage their students in math and science, particularly female students.

Overall we received very positive feedback. Some comments that we received were "[The teleconference] was a well-rounded perspective on engineering and preparing students for engineering careers." Another participant "[I] felt that the information was extremely informative and looked forward to becoming a part of other programs." The majority felt that the teleconference met their expectations. They felt that the panelist were knowledgeable, found the videos of engineers working in the field very useful, and would recommend this teleconference to a friend. When asked how satisfied they were with the amount of information delivered on each topic we found that many participants would have liked to have more information on the "fun engineering" and the "women in engineering" sections.

\section{Future plans}

As a result of the success and feedback received from the first teleconference, the focus of our second teleconference in the "Building an Engineer" series will be on women in engineering. It was found that there was so much information to be shared on the subject of women in engineering and not enough time to cover it in just one twenty minute segment. The subject of Women in Engineering needs and deserves a full teleconference on its own.

This "Building An Engineer: Women in Engineering" teleconference is scheduled to take place on May 6, 2003. Through this teleconference session, educators will be introduced to a panel of experts who will discuss gender issues in engineering education and engineering careers. After 
participating in this teleconference, educators will be better informed of the shortage of female engineers, the importance of encouraging young women to take advanced mathematics and science classes, and how to help female students build confidence in their mathematics and science abilities.

In the first teleconference, we videotaped several engineers of which many were women. Hopefully these women engineers, as well as the women on the panel, will serve as role models. More female engineers will be seen in the next teleconference along with information on issues facing women in engineering; networking opportunities, and available scholarship. We also hope that our panel and video testimonials will show the challenging, fun and social aspects of engineering.

Four primary themes will be discussed during the Women in Engineering teleconference:

- Underrepresentation of women in engineering

- Pre-College Program for girls

- Issues faced by female engineering students

- Issues faced by women in industry

Although there have been some strides made for women in engineering, we still need to promote awareness of these issues so that educators encourage more girls to pursue this field. The problem is not only getting women interested in engineering but also retaining them through graduation. It is important for stakeholders to understand the reasons why there is a shortage of women in engineering and why women are important to the profession. In addressing these issues, we hope to foster a more supportive environment for women as they pursue their degree.

\section{Conclusion}

The percentage of women has been gradually rising in most formerly male-dominated professions; however, the opposite appears to be occurring in engineering ${ }^{[4]}$. The number of women entering engineering has been historically low. Nevertheless, change will not begin until the reasons are recognized. We must present reason for and relevance of math and science to young girls in a fashion they can relate to and also increase visibility of female role models in engineering.

Stakeholders need to provide encouragement and incentives for "trying" to succeed in these areas.

\section{Bibliography}

[1] Campbell, P.B., and Clewell, B.C., "Science, math, and girls", Education Week, Vol.19, No. 2, September 15,1999 , pp. $50+$

[2] Austin, A., "The Changing American College Student: Thirty Year Trends, 1966-1996" The Review of Higher Education 21 (1998): 115-35

[3] JobWeb.com — Career development and job search help for college graduates. Copyright (C National Association of Colleges and Employers 
[4] Widnall, Sheila E. (2000). Digits of Pi: Barriers and Enablers for Women in Engineering. The Bridge Magazine Volume 30

[5] Koppel, N., Cano, R., Heyman, S., "An attractive engineering option for girls", Proceedings for the $32^{\text {nd }}$ ASEE/IEEE Frontiers in Education Conference, Boston, MA, Nov, 2002

[6] Cano, R., Kimmel, H., Koppel, N., Muldrow, D., "A First Step for Women into the Engineering Pipeline", Proceedings for the $31^{\text {st }}$ ASEE/IEEE Frontiers in Education Conference, Reno, NV, Oct. 2001

[7] Abrams, L.M., Fentiman, A.W., "An Integrated Program to Recruit and Retain Women Engineering Students", Proceedings of the 2002 ASEE Annual Conference, Montreal, QC, June, 2002

[8] Workman, J., "Development of a K-12 Summer Program to Promote Women in Engineering and Technology, Proceedings of the 2001 ASEE Annual Conference, Albuquerque, NM, June, 2001

[9] Congressional Commission on the Advancement of Women and Minorities in Science, Engineering and Technology Development report, "Land of plenty," September 2000

[10] Cole, J. R. (1979). Fair Science: Women in the Scientific Community. New York: The Free Press

[11] New Jersey Commission on Higher Education. Higher Education Outcomes and High-Tech Workforce Demands: The Fifth Annual Systemwide Accountability Report, March 2001

SUZANNE B. HEYMAN is the Educational Technology Specialist for PrE-IOP. She has a B.S. in Education and an M.A. in Educational Communication, and Technology. She holds a New Jersey Teaching Certificate and has taught in New Jersey schools. .Ms. Heyman's activities include professional development workshops, in-class support, curriculum development, development of evaluation tools, and educational technology support for teachers.

AISHA K. LAWREY is the Project Manager for the Outreach component of PrE-IOP. She has a B.E. in Electrical Engineering from Stevens Institute of Technology. Previously she was an instructor for the Consortium for PreCollege Education at UMDNJ. She volunteers as an Instructor at the Boys \& Girls Clubs of Newark. Over the last seven years she has worked with the National Society of Black Engineers (NSBE) Pre-College Initiative Program.

RONALD H. ROCKLAND is a Co-P I for PrE-IOP. He is an Associate Professor of Electrical and Computer Engineering Technology and Biomedical Engineering at NJIT and Associate Dean of Engineering. He is a co-PI of the New Jersey - DoE "Tech-Prep Program", Project Director of a Whitaker Foundation "Industrial Internship for Biomedical Engineering Students" grant, and an investigator for a NJIT/Gateway Professional Development Project. 